\title{
COMPRESSIVE TESTS OF BASES FOR SUBWAY COLUMNS
}

\author{
By James H. Edwards, H. L. Whittemore, and A. H. Stang
}

ABSTRACT

In the construction of subways under the streets for carrying passengers by electric trains it is customary to provide steel columns between the tracks to support the overhead structure. These columns are usually rolled steel $\mathrm{H}$-sections having plate and angle bases riveted to the columns for distributing the load on the concrete footing.

Tests were made of 3 welded bases and 6 riveted bases, 3 without base plates, and 3 with base plates to determine whether the welded design was satisfactory.

The specimens were loaded with the base on a span of 12 inches.

Some hand strain-gage readings were taken to study the stress distribution.

The strength of the welded specimens and the riveted specimens having base plates was practically the same. The H-section deformed greatly at the maximum load, and the stiffeners in the base buckled.

The strength of the riveted specimens without base plates was about 60 per cent of the strength of the other types. At failure, eight rivets on one side of the specimen sheared. There was apparently no deformation of either the $\mathrm{H}$ section or the angles forming the base.

\section{CONTENTS}

619

II. Method of testing 620

1. Loading the specimens. 620

2. Strain gage measurements 620

III. Results of the tests with discussion

1. Strength of the bases... 622

2. Stresses

(a) Stresses in the stiffeners

(b) Stresses in the H-section. 624

IV. Conclusions

\section{THE COLUMN BASES}

In the construction of subways under the streets for carrying passengers by electric trains it is customary to provide steel columns between the tracks to support the overhead structure. These columns are usually rolled steel $\mathrm{H}$-sections having plate and angle bases riveted to the column for distributing the load on the concrete footing.

The American Bridge Co. suggested to the Interborough Rapid Transit Co., of New York City, that the bases be welded instead of riveted and that the design of the base be changed to one which was more suitable for this new method of fabrication. The welded base consisted of only three plates, as shown in Figures 1, 5, and 8. Six angles and two plates were required for the riveted base having no base plate, as shown in Figures 1 and 8 , six angles and three plates for the riveted base having a base plate, as shown in Figures $1,2,3$, 7 , and 8 . 
As the welded design was a radical departure from the method of fabricating these important connections, which experience had shown to be satisfactory, tests were made to determine the strength of 3 welded bases and 6 riveted bases, 3 without base plates and 3 with base plates. Some hand strain-gage readings were taken to study the stress distribution.

The American Bridge Co. made the designs and fabricated the specimens. The tests were made by the National Bureau of Standards.

\section{METHOD OF TESTING}

\section{LOADING THE SPECIMENS}

The specimens rested on two blocks, $A-A$, having cylindrical lower surfaces as shown in Figure 2. The blocks rested on a hardened steel plate, $B$. The blocks were 6 inches wide and 10 inches long: The radius of the cylindrical surface was 4 inches. The distance between the inner surfaces of the blocks, 6 inches, was about the nominal depth (5.986 inches) of the H-section. The span was, therefore, 12 inches. A hardened steel plate, $C$, was placed on top of the $\mathrm{H}$-section and the load applied through a spherical bearing, $D$.

With an assumed yield point of $35,000 \mathrm{lbs}$./in., ${ }^{2}$ the $\mathrm{H}$-sections (sectional area 14.70 square inches) would be expected to fail in ('ompression under a load of about 500,000 pounds. The testing' machine having a capacity of 600,000 pounds was therefore used for these tests. The riveted bases without base plates failed when loaded in this machine, but as the other specimens did not fail under a load of 600,000 pounds, greater loads were later applied in the hydraulic testing machine having a capacity of $10,000,000$ pounds. (See fig. 3.) Since the lower platen of this machine has a spherical seat, no spherical bearing was used on top of the $\mathrm{H}$-section.

\section{STRAIN GAGE MEASUREMENTS}

To determine the stresses in some portions of the specimens, hand strain-gage readings were taken on the gage lines (shown in fig. 1) with a Whittemore fulcrum-plate strain gage having a 2-inch gage length. This strain gage (shown in fig. 4.) was designed by one of the authors at the request of the Engineering Foundation, Committee on Arch Dam Investigation. ${ }^{1}$ For that investigation a more accurate strain gage was desired than the instruments then available.

The frame of this instrument consists of two parallel side bars connected near their ends by spring fulcrum plates which effectively prevent motion of one bar relative to the other, except longitudinally. The two points (for insertion in holes in the member upon which the measurements are to be taken) are rigidly attached, one to each side bar. The relative movement of the side bars is, for an instrument having a 2-inch gage length, usually indicated by a "Last Word" dial micrometer graduated to $1 / 10,000$ inch and having a range of 0.024 inch. Although the accuracy of the readings of ihis strain gage depends somewhat upon the skill of the observer, the error in the stress computed from the readings taken with this instrument having a 2-inch gage length, probably, did not exceed

1 Engineering Foundation Committee on Arch Dam Investigation, Report by Committee, 1, published by Am. Soc. of Civil Engrs., Strain-Gage, D. 64; May, 1928. 


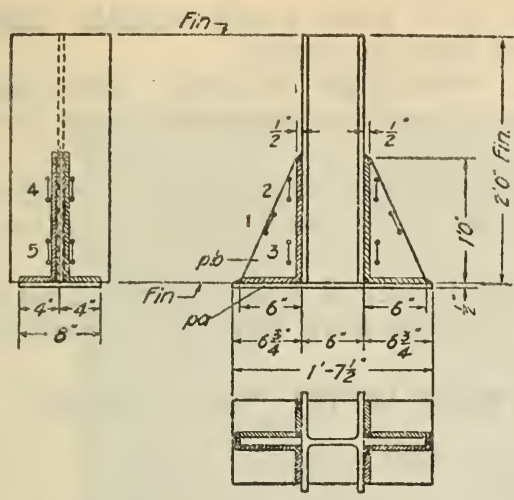

Welded

\begin{tabular}{|c|c|c|c|c|}
\hline \multicolumn{5}{|c|}{ BILL OF MATERIAL } \\
\hline No. & Shape & \multicolumn{2}{|c|}{ Lenath } & \multirow{2}{*}{ Remarks } \\
\hline & $\sigma^{\circ} h-C B \sigma /-50 / b$ perfos & $F t$ & $\ln$. & \\
\hline 1 & Plate $-8=1 / 2$ & $\frac{2}{1}$ & $7 / 2$ & pa \\
\hline 2 & Plates-6"x $3 / \mathrm{f}^{\prime}$ & 1 & 0 & 26 \\
\hline & & & & \\
\hline & & & & \\
\hline & & & & \\
\hline & & & & \\
\hline & & & & \\
\hline & & & & \\
\hline
\end{tabular}
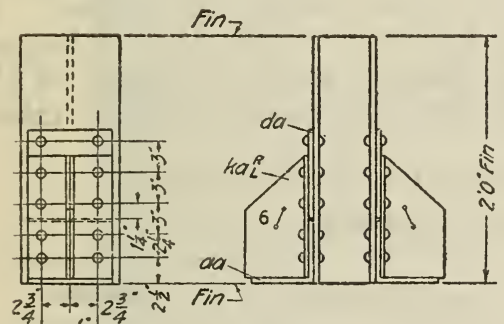

Fin' $2 \frac{3}{4}-5 \frac{1}{2}=T^{-1}$

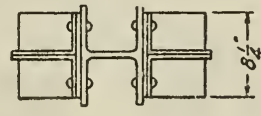

Rivered, No Base Plate

\begin{tabular}{|c|c|c|c|c|}
\hline \multicolumn{5}{|c|}{ BILL OF MATERIAL } \\
\hline No. & \multirow{2}{*}{ Shape } & \multicolumn{2}{|c|}{ lenath } & Remarks \\
\hline$c=$ & & $F t$ & h.7. & kemarks \\
\hline 1 & 6"H-CBSI-SOlkperfft. & 2 & 0 & fin \\
\hline 2 & Angles- $6^{\circ} \times 6^{\circ} \times 7 / 16^{\circ}$ & 0 & $8 / 1 / 4$ & aa \\
\hline 4 & Angles $-6^{\circ} \times 4^{-1} \times 3 / 8$ & 0 & 1136 & kấfFin \\
\hline 2 & Plates-8. $x^{-2} / 15^{\circ}$ & 0 & $81 / 2$ & dá \\
\hline & & & & \\
\hline & & & & \\
\hline & & & & \\
\hline & & & & \\
\hline & & & & \\
\hline
\end{tabular}

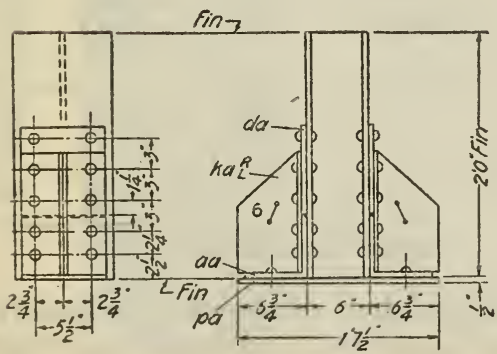

Riveted, Barse Plate

\begin{tabular}{|c|c|c|c|c|}
\hline \multicolumn{5}{|c|}{ BILL OF MATERIAL } \\
\hline \multirow{2}{*}{$\begin{array}{l}\mathrm{Na} \\
\text { FCS. }\end{array}$} & \multirow[b]{2}{*}{ Shape } & \multicolumn{2}{|c|}{ Lerigtin } & \multirow[b]{2}{*}{ Fernarks } \\
\hline & & Ft. & $\ln$. & \\
\hline 1 & $6^{\prime \prime} \mathrm{H}-\mathrm{CB} 6 \mathrm{l}-50 / 6.0 \mathrm{f} f \mathrm{t}$ & 2 & 0 & Fin \\
\hline 2 & Angles $-6^{\circ} \times 6^{\circ} \times 7 / 6^{\prime \prime}$ & 0 & $8 / / 2$ & ar \\
\hline 4 & Anales- $6 \times 4^{\circ} \times 3 / 8^{\circ}$ & 0 & $1 \% \%$ & haif fin \\
\hline 2 & Plates-8. $\times 7 / 16^{\circ}$ & 0 & $81 / 2$ & da \\
\hline 1 & Plate $-8^{-1} \times 1 / 2^{\circ}$ & 1 & $7 / 3$ & $p a$ \\
\hline & & & & \\
\hline & & & & \\
\hline & & & & \\
\hline & & & & \\
\hline
\end{tabular}

FIGURE 1.-Dimensioned drawing of bases for subway columns 
2,000 lbs./in. ${ }^{2}$ The error would have been much smaller (about 500 lbs./in. ${ }^{2}$ ) if the gage length had been 10 inches.

On the riveted column bases, strain-gage readings were taken only on the four inclined gage lines, 6 , on the outstanding leg of the stiffener angles.

Twenty gage lines were used on the welded specimens as shown in Figure 1 to obtain a better knowledge of the stress distribution in this new design.

To allow the average stress to be determined if the stiffener buckled, the gage lines 1,2 , and 3 were placed on both sides of the stiffener.

\section{RESULTS OF THE TESTS WITH DISCUSSION}

\section{STRENGTH OF THE BASES}

The results of the compressive tests are given in Table 1. In addition to the strength a "yield point" was obtained by observing either the load at which the beam of the testing machine "dropped" or the load which remained constant as the specimen shortened. As it was necessary to stop the testing machine to take the strain-gage readings, it was difficult to detect "yield points" by "drop of the beam" at loads near those at which strain-gage readings were taken.

\section{TABLE 1.-Results of compressive tests of column bases}

[Nominal area of $\mathrm{H}$-section, 14.70 square inches]

\begin{tabular}{|c|c|c|c|c|c|}
\hline \multirow[b]{2}{*}{ Column base No. } & \multirow[b]{2}{*}{ Description of specimens } & \multicolumn{2}{|c|}{ Yield point } & \multicolumn{2}{|c|}{ Strength } \\
\hline & & Total load & $\begin{array}{l}\text { Stress in } \\
\text { H-section }\end{array}$ & Total load & $\begin{array}{l}\text { Stress in } \\
\text { H-section }\end{array}$ \\
\hline \multirow[t]{2}{*}{$\begin{array}{l}\text { TC } 1-A \\
\text { TC } 1-B . \ldots \\
\text { TC } 1-C . . .\end{array}$} & $\begin{array}{l}\text { Welded } \\
\text { Wendo }\end{array}$ & $\begin{array}{l}\text { Pounds } \\
1412,000 \\
444,000 \\
448,000 \\
\end{array}$ & $\begin{array}{r}\text { Lbs./in. }{ }^{2} \\
28,000 \\
30,200 \\
30,500 \\
\end{array}$ & $\begin{array}{c}\text { Pounds } \\
623,000 \\
666,000 \\
661,000 \\
\end{array}$ & $\begin{array}{r}\text { Lbs./in.2 } \\
42,400 \\
45,300 \\
45,000 \\
\end{array}$ \\
\hline & A verage... & $-\ldots \ldots . .$. & 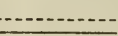 & $-\cdots$ & 44,200 \\
\hline \multirow[t]{2}{*}{$\begin{array}{l}\text { TC 2-A } \\
\text { TC 2-B } \\
\text { TC } 2-\mathrm{C} \text {. }\end{array}$} & Riveted, no base plate & $\begin{array}{l}395,000 \\
353,000 \\
367,000 \\
\end{array}$ & $\begin{array}{l}26,900 \\
24,000 \\
25,000\end{array}$ & $\begin{array}{l}419,000 \\
426,000 \\
416,000\end{array}$ & $\begin{array}{l}28,500 \\
29,000 \\
28,300\end{array}$ \\
\hline & A verage. & & & 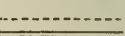 & 28,600 \\
\hline \multirow[t]{2}{*}{$\begin{array}{l}\text { TC 3-A } \\
\text { TC } 3-\mathrm{B}-\ldots \\
\text { TC } 3-\mathrm{C}-\ldots\end{array}$} & $\begin{array}{l}\text { Riveted, base plate } \\
\text { do }\end{array}$ & $\begin{array}{l}435,000 \\
446,000 \\
440,000\end{array}$ & $\begin{array}{l}29,600 \\
30,400 \\
29,900\end{array}$ & $\begin{array}{l}698,000 \\
683,000 \\
676,000\end{array}$ & $\begin{array}{l}47,500 \\
46,500 \\
46,000\end{array}$ \\
\hline & $50-$ & & & & 46,600 \\
\hline
\end{tabular}

${ }^{1}$ At this load no drop of the beam was observed, but the stiffeners were buckled.

The first indication of failure in the welded specimens was buckling of the stiffener plates. The $\mathrm{H}$-section deformed as the load increased. The welded specimen TC $1-A$ after test is shown in Figure 5. All the welded specimens failed in much the same way. In only one of the welded specimens, TC $1-A$, was a crack in the weld detected. It was not observed until after the specimen was removed from the testing machine. It was at $A$ (fig. 5 ) between the outer surface of the flange of the $\mathrm{H}$-section and the weld metal and extended along the weld for about three-fourths inch. It was probably caused by the increase in the angle between the base plate and the flange of the H-section 
B. S. Journal of Research. RP219

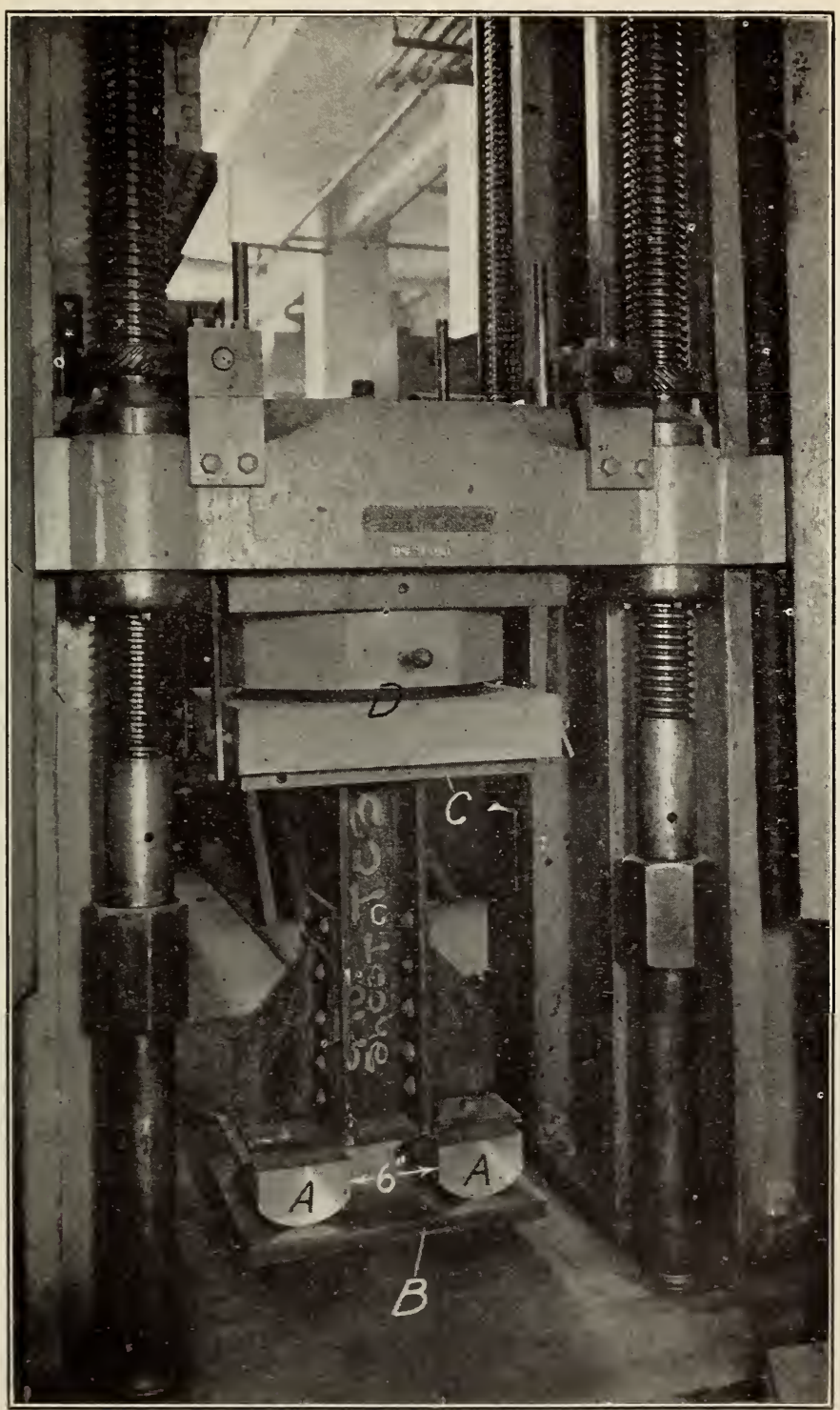

FIGURE 2.-Specimen ready for test in the testing machine having a capacity of 600,000 pounds.

The base was supported on a span of 12 inches by blocks having cylindrical (radius 4 inches) lower surfaces. A spherical bearing block was placed on top of the specimen. This specimen is riveted base TC $3-\mathrm{C}$ having a base plate. 
B. S. Journal of Research, RP218

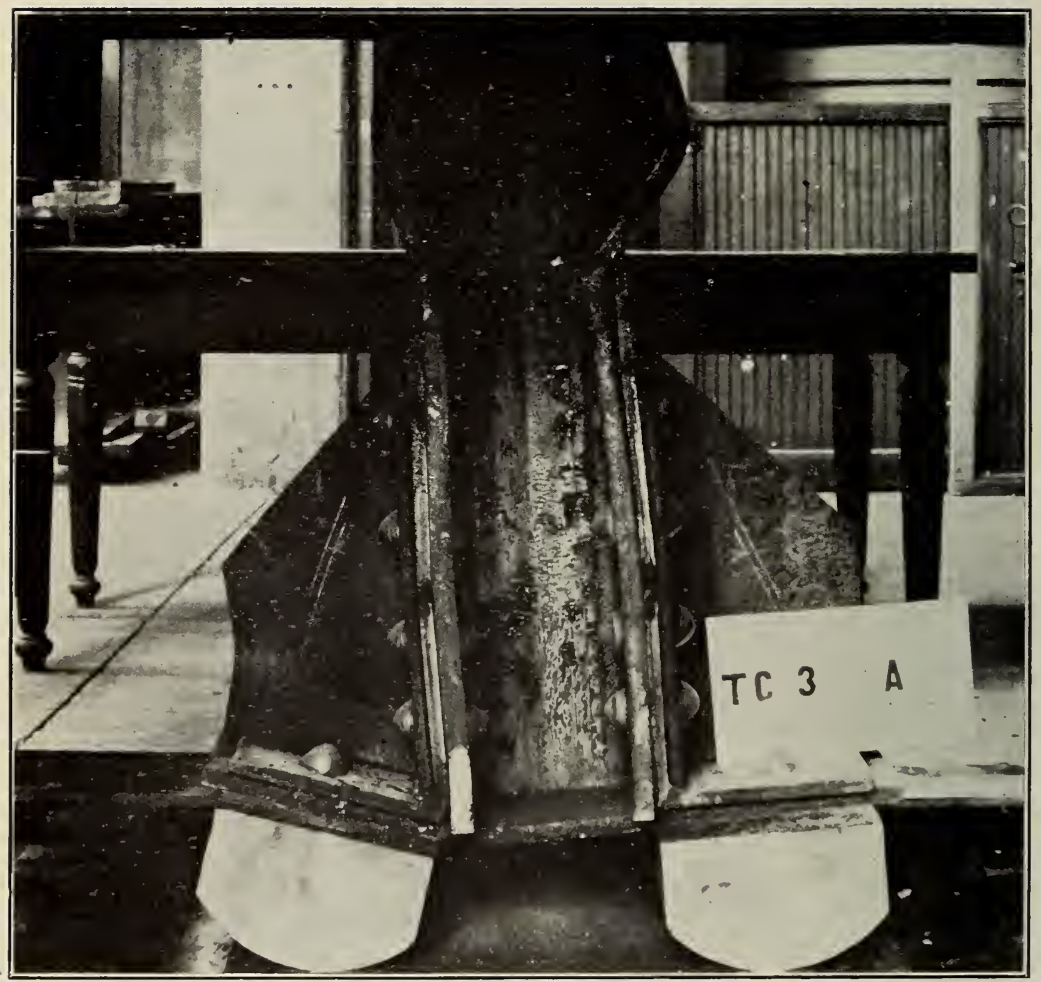

FIGURE 3.-A specimen after test in the testing machine having a capacity of $10,000,000$ pounds

This is the riveted base TC $3-A$ having a base plate. The total load was 698,000 pounds and the average stress in the $\mathrm{H}$-section was $47,500 \mathrm{lbs}$./in. ${ }^{2}$ 


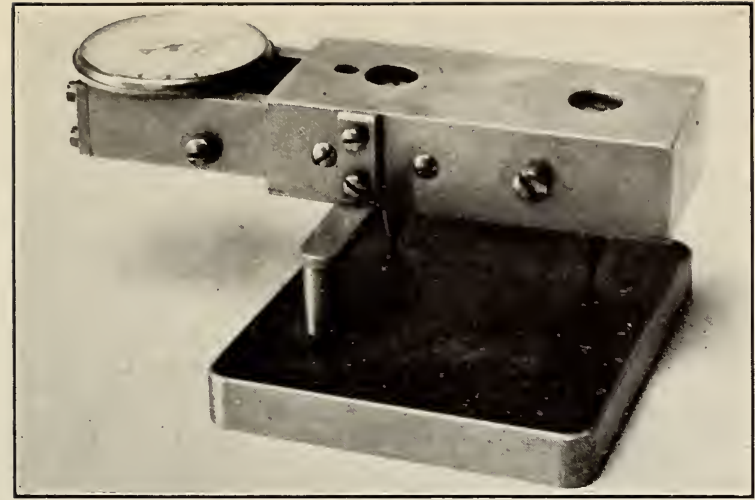

FIGURE 4.-The Whittemore fulcrum plate strain gauge having a gauge length of 2 inches

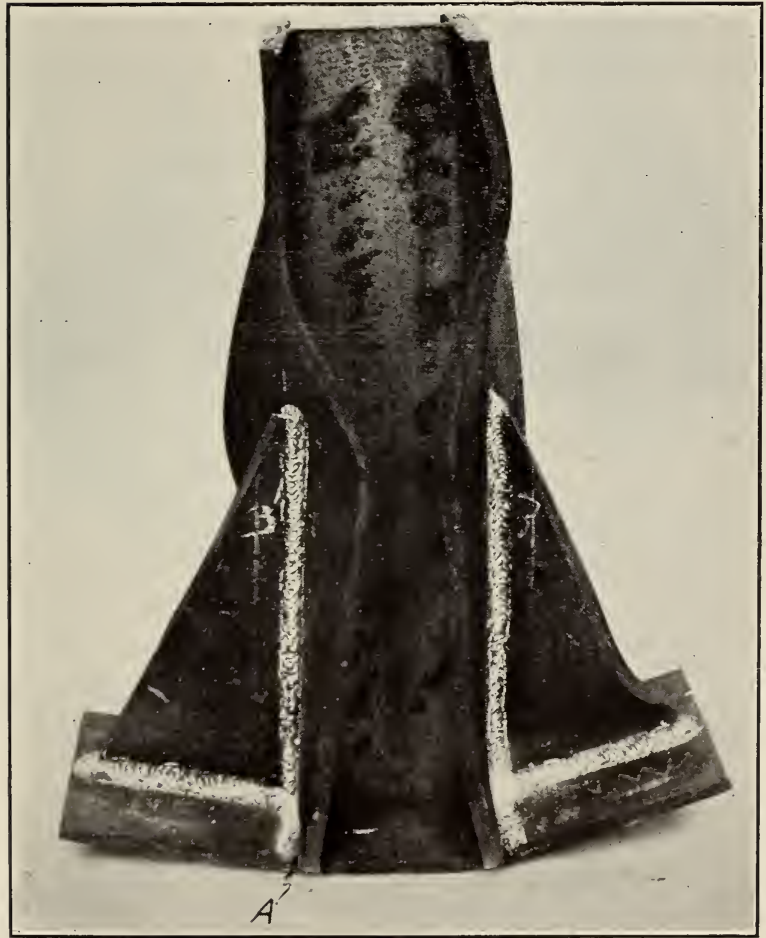

Figure 5.-The welded base TC 1-A after test

The total load was 623,000 pounds and the average stress in the $\mathrm{H}$-section was $42,400 \mathrm{lbs}$./in. ${ }^{2}$ The crack shown at A was the only one detected in a weld for the three specimens of this type. 
B. S. Journal of Research, RP218

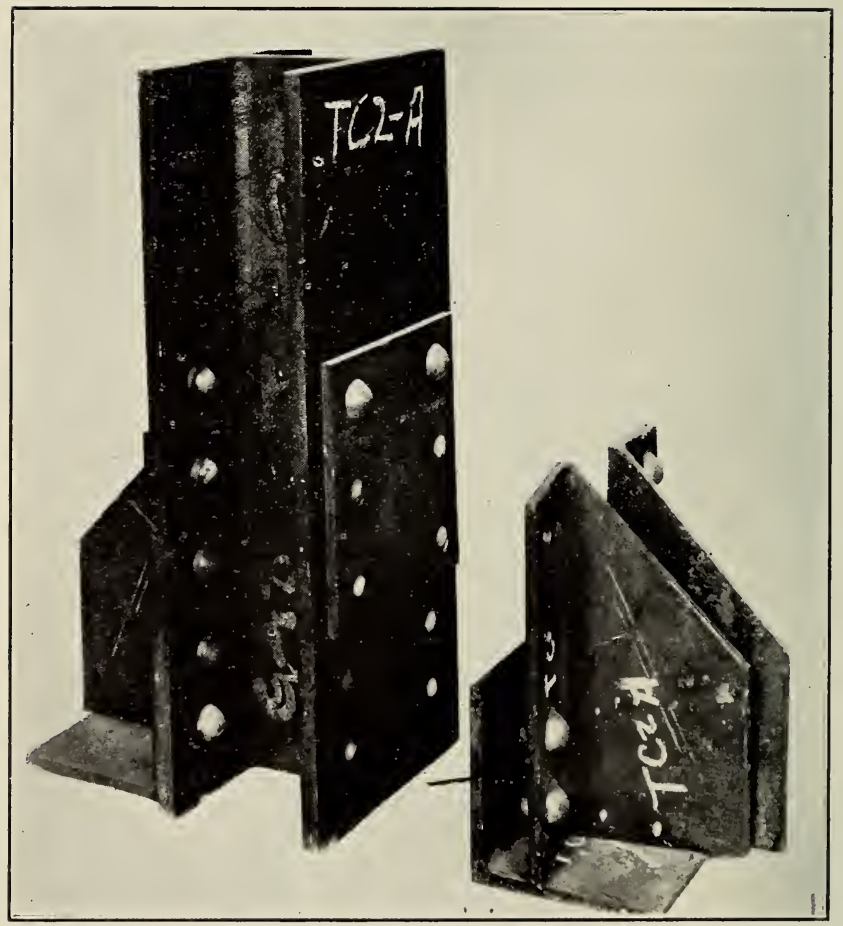

Figure 6.-The riveted base TC 2-A without base plate, after test

The eight rivets on one side of the specimen sheared. The total load was 418,000 pounds, and the average stress in the $\mathrm{H}$-section was $28,480 \mathrm{lbs}$. $/ \mathrm{in} .^{2}$ The average shearing stress in the sixteen $3 / 4$-inch rivets was $59,400 \mathrm{lbs}$./in. ${ }^{2}$ 
when the $\mathrm{H}$-section deformed. The crack was so small that it could have had no effect on the results of the test.

All the riveted specimens without base plates failed by shearing the eight rivets on one side. Specimen TC 2-A after test is shown in Figure 6 . There was no noticeable deformation of the H-section nor of the pieces forming the base.

The computed average maximum shearing stress in these rivets, using the nominal area of the 16 three-fourth-inch rivets, was 59,400 lbs./in. ${ }^{2}$

The failure of the riveted specimens with base plates was similar to that of the welded specimens as may be seen in Figures 3 and 7 . The outstanding legs of the stiffener angles buckled, several rivets sheared, and the $\mathrm{H}$-section deformed.

The strength of these particular welded specimens was practically the same as the strength of these particular riveted specimens having base plates. The strength of the riveted specimens without base plates was 61 per cent of the strength of the riveted specimens having base plates. Unfortunately no tensile specimens of the steel in these column bases were provided by the fabricator. There is no record as to whether the $\mathrm{H}$-sections were cut from the same or from different lengths. It is therefore impossible to draw general conclusions from the results of the tests. As there was considerable deformation of the $\mathrm{H}$-sections for the welded and riveted base-plate specimens and comparatively little deformation of the base, it is probable that the maximum load was determined by the strength of the H-section.

As the maximum compressive strength of columns decreases as the length increases, the strength of the short $\mathrm{H}$-sections used for these tests was greater than the strength of any longer column having the same section. It may also be pointed out that the bases, when in use, rest on flat surfaces supported by the foundation of the subway. Since these bases were tested on blocks which were spaced 12 inches center to center, they were, therefore, tested under more severe conditions than those which could occur in service.

\section{STRESSES}

The location of the gage lines on which strain gage readings were taken is shown in Figure 1. The stress along a gage line was computed ${ }^{2}$ by multiplying the change in the length of the gage line by the assumed Young's modulus of elasticity of 29,000,000 lbs./in. ${ }^{2}$ for the steel. The readings for gage lines similarly located were averaged for specimens of the same type.

\section{(a) STRESSES IN THE STIFFENERS}

The stresses in gage No. 1 on the stiffener plates of the welded specimens, TC 1, may be compared with those in gage No. 6 on the stiffener angles of the riveted specimens TC 2 and TC 3 . It should be remembered that the combined thickness of the two angles in the riveted specimens (three-fourth inch) is equal to the thickness of the stiffener plates in the welded specimen.

For convenience in plotting the graphs of Figure 8, the ordinates are the average stresses in the $\mathrm{H}$-section computed from the load indi-

${ }^{2}$ For method of computing stress from strain-gage readings, refer to B. \&. Tech. Paper No. 260, "Tests of Some Girder Hooks," by Whittemore and Stang, p. 310 . 
cated on the beam of the testing machine, while the abscissas are the stresses computed from the strain-gage readings. Each plotted point is the average of the six readings obtained for the two gage lines on opposite sides of the specimen for each of the three specimens. The stress in the stiffener plate (gage No. 1) is proportional to the average stress on the $\mathrm{H}$-section up to about $18,000 \mathrm{lbs} . / \mathrm{in} .^{2}$ and is more than iwice the stress in the stiffener angles of the riveted specimens (gage No. 6). This shows that the riveted base is stifier than the welded. The gage lines, Nos. 1 and 6, are in the same position relative to the base and the columa. The greater stifiness of the riveted specimens is undoubtedly due to the fact that the stiffeners on the riveted bases had considerably more metal outside the gage lines than the stiffeners on the weided base. For higher loads the stresses in the stiffener plates increased much more rapidly than the average stress in the H-section, and eventually caused bucliling.

The stress in the riveted specimens was proportional to the average stress in the H-section and was practicaliy the same for the specimens with and without base plates.

Although base plates on the riveted specimens increased the maximum load about 60 per cent, they did not increase the stiffness of the base for loads below the yield point.

The stresses in the vertical gages Nos. 2 and 3 (fig. 1) on the stiffener plates of the welded specimens are plotted in Figure 8 . The stress in gage No. 2,9 inches above the base, was directly proportional to the average stress in the $\mathrm{H}$-section throughout the loading range for which strain measurements were taken.

The stresses in gage No. 3,3 inches above the base, were about the same as those in gage No. 2 up to about 8, 000 lbs./in. ${ }^{2}$ For higher loads, however, the stresses in gage No. 3 increased more rapidly than the stress in gage No. 2 and were much less than those in the inclined gage No. 1. It appears probable that the upward forces exerted on the specimen by the blocks, A-A (fig. 2), caused high compressive stresses in the stiffeners above the blocks. Although gage No. 3 was not vertically over the block, it was in the portion of the stiffener which was highly stressed.

\section{(b) STRESSES IN THE H-SECTION}

Strain grage readings on the H-section were obtained on only the welded specimens, $\mathrm{TC}_{1}$. These gage lines (fig. 1) were vertical and centered 9 inches for gage No. 4 and 3 inches for gage No. 5 above the lower end of the H-section. The stresses on these gage lines have been plotted in Figure 8 . The dashed line is inclined $45^{\circ}$ to the axes and may, therefore, be called a line of theoretical stress since, if the load on the H-section was uniformly distributed over the cross-section, the strain-gage stresses would equal the average stress computed from the total load on the specimen. Because of the stiffeners and the base plate and the fact that the specimen was supported on a span of 12 inches, it is obvious that a uniform stress distribution should not be expected near the base of the H-section. Figure 8 shows that the stresses in gage No. 4, 9 inches from the bottom of the $\mathrm{H}$-section, were less than the average stress in the $\mathrm{H}$ section for low loads, but practically equal the average at 26,000 lbs./in. ${ }^{2}$ The stresses in this gage line were proportional to the 


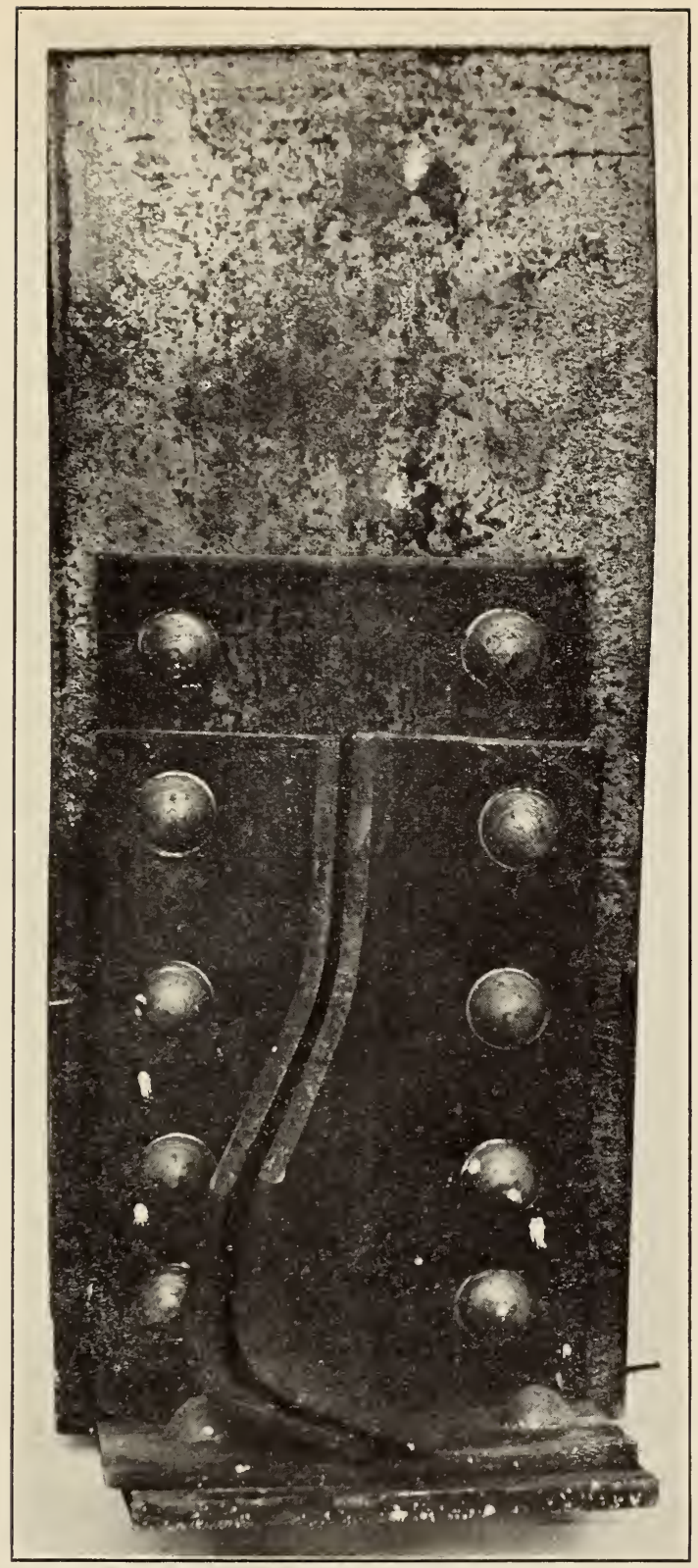

Figure 7.-The riveted base TC 3-C having base plate, after test

The total load was 676,000 pounds, and the average stress in the $\mathrm{H}$-section was $46,000 \mathrm{lbs}$./in. ${ }^{2}$ 

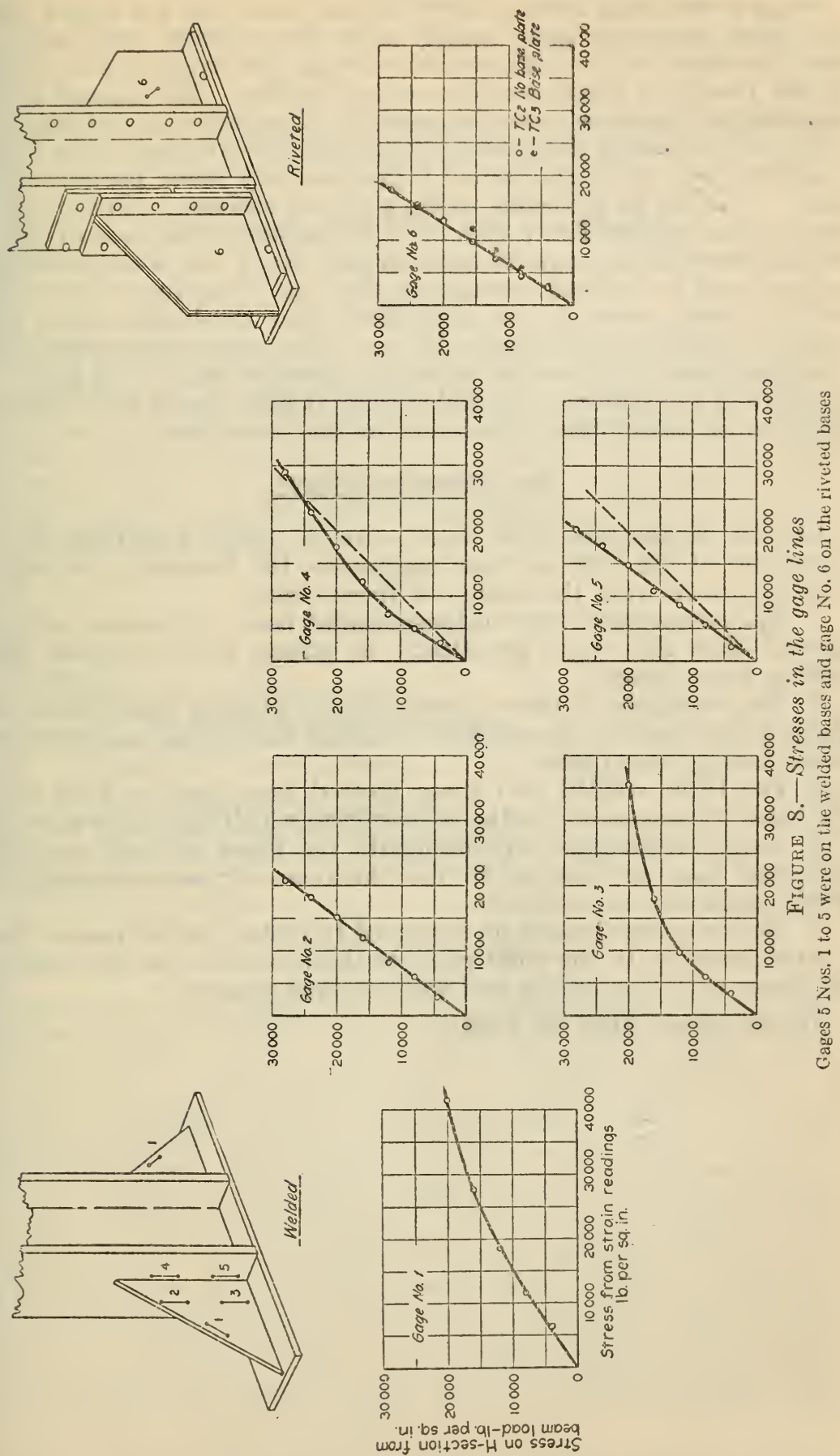
average stress from zero to $8,000 \mathrm{lbs}$./in. ${ }^{2}$ load, but for higher loads the stress increased more rapidly than the average, and indicated that the effect of the stiffeners in reducing the stress in this portion of the $\mathrm{H}$-section flange was decreasing rapidly. The change in the direction of the stress curve for gage No. 1, gage No. 3, and gage No. 4 (fig. 8), indicates that above $12,000 \mathrm{lbs}$./in. ${ }^{2}$ average stress in the $\mathrm{H}$-section, the stiffeners carried a progressively lower portion of the load. It might be advisable to use a thicker stiffener. For low loads the stresses in gage No. 5 (fig. 8), 3 inches above the base of the $\mathrm{H}$ section, were about equal to those in gage No. 4 and were practically proportional to the load throughout the test, being about 70 per cent of the average stress in the H-section. For the higher loads, they were lower than those in gage No. 4. The stress in the web of the $\mathrm{H}$-section, near the base plate must, therefore, have been low. At gage No. 5 the stiffener was wider than at gage No. 4 and was more effective in transmitting the forces to the H-section.

\section{CONCLUSIONS}

On the assumption that there were no great variations in the properties of the steel in these specimens, the following conclusions may be drawn from the results of these tests:

1. The compressive tests of these welded bases for subway columns showed that they were practically as strong as the riveted bases having base plates.

2. The strength of these riveted bases without base plates was about 60 per cent of the strength of either the welded or the riveted bases having base plates.

3. For these welded and these riveted bases having base plates the bases were as strong as the $\mathrm{H}$-section to which they were attached.

4. Hand strain-gage measurements on these welded specimens indicated that an increase in the thickness of the stiffener plates would make the bases stiffer.

5 . With the base loaded on a span of 12 inches the stiffness of these riveted bases up to the yield point of the $\mathrm{H}$-section was the same for the bases with base plates and without base plates.

Washington, May 28, 1930. 